\title{
Cross-clade CTL recognitions for clade $B$ and A/E viruses in $A / E$ virus-infected Japanese individuals
}

\author{
K Watanabe ${ }^{1 *}$, H Murakoshi ${ }^{1}$, M Koyanagi ${ }^{1}$, Y Tamura ${ }^{1}$, R Maruyama ${ }^{1}$, T Chikata ${ }^{1}$, H Gatanaga ${ }^{2}$, S Oka², \\ M Takiguchi ${ }^{1}$
}

From AIDS Vaccine 2012

Boston, MA, USA. 9-12 September 2012

\section{Background}

Cytotoxic T lymphocytes (CTLs) play an important role in the control of HIV-1. CTL responses to HIV-1 have been well studied in HIV-1 clade B-infected and clade $\mathrm{C}$-infected individuals. However cross-clade CTL recognitions have not been well analyzed. In this study, we analyzed cross-clade CTL recognition for clade $B$ and $\mathrm{A} / \mathrm{E}$ viruses in $\mathrm{A} / \mathrm{E}$ virus-infected Japanese individuals.

\section{Methods}

PBMC samples were collected from chronically HIV-1 infected Japanese cohort in NCGM. Twenty-six clade A/ E-infected individuals were analyzed by ELISPOT assay using the 11-mer overlapping peptides and then the responses of CTLs to these peptides was compared to those from 402 clade B-infected Japanese individuals. Thereafter CTL responses to each single peptide and to truncated peptides were evaluated by ELISPOT assay and intracellular cytokine staining (ICC) assay, respectively.

\section{Results}

Similar level of CTL responses to Gag, Pol and Nef were found in clade $\mathrm{A} / \mathrm{E}$-infected individuals as compared to that in clade B-infected ones. We identified 15 cross-clade CTL epitopes from 14 cocktails where the frequency of responders was high in clade $\mathrm{A} / \mathrm{E}$ infected samples. The sequences of 7 epitopes were conserved between clade $B$ and clade $\mathrm{A} / \mathrm{E}$ viruses, whereas 8 epitopes showed different amino acid sequences between two viruses. In these 8 epitope regions, we confirmed cross-clade CTL recognition by ICC assay using clade A/E consensus sequence peptide.

\section{Conclusion}

Cross-clade CTLs were predominantly induced in clade $\mathrm{A} / \mathrm{E}$-infected individuals by clade $\mathrm{B}$ consensus sequence peptides in this study. Moreover, CTL responses were induced not only in conserved region but also in different sequence region between the 2 viruses, indicating that polymorphic sequence epitopes among clades can be also candidate for the target of CTL-based vaccines. Further analysis of cross-clade CTL recognition is needed for the widely applicable vaccine development.

\section{Author details}

${ }^{1}$ Kumamoto University, Tokyo, Japan. ${ }^{2}$ AIDS Clinical Center, National Center for Global Health and Medicine, Tokyo, Japan.

Published: 13 September 2012

doi:10.1186/1742-4690-9-S2-P251

Cite this article as: Watanabe et al: Cross-clade CTL recognitions for clade $B$ and $A / E$ viruses in $A / E$ virus-infected Japanese individuals. Retrovirology 2012 9(Suppl 2):P251.

Submit your next manuscript to BioMed Central and take full advantage of:

- Convenient online submission

- Thorough peer review

- No space constraints or color figure charges

- Immediate publication on acceptance

- Inclusion in PubMed, CAS, Scopus and Google Scholar

- Research which is freely available for redistribution

'Kumamoto University, Tokyo, Japan

Full list of author information is available at the end of the article 